\title{
Skin Squamous Cell Carcinoma or Other Skin Carcinomas cM1 TNM Finding v7
}

National Cancer Institute

\section{Source}

National Cancer Institute. Skin Squamous Cell Carcinoma or Other Skin Carcinomas CM1

TNM Finding v7. NCI Thesaurus. Code C88496.

Skin squamous cell carcinoma or other skin carcinomas with distant metastases. (from AJCC 7th Ed.) 